DOI 10.1590/S0104-64972015002327

\title{
Primitive decapods from the deep sea: first record of blind lobsters (Crustacea: Decapoda: Polychelidae) in northeastern Brazil
}

\author{
Luis Ernesto Arruda Bezerra and Felipe Bezerra Ribeiro
}

(LEAB) Instituto de Ciências do Mar, Universidade Federal do Ceará. Av. da Abolição, 3207, 60165081 Fortaleza, Ceará, Brazil. E-mail: luiseab@gmail.com

(FBR) Programa de Pós-graduação em Biologia Animal, Departamento de Zoologia (Laboratório de Carcinologia), Instituto de Biociências, Universidade Federal do Rio Grande do Sul. Av. Bento Gonçalves, 9500, pr. 43435. 91501-970 Porto Alegre, Rio Grande do Sul, Brazil.

\begin{abstract}
We report herein the occurrence of the infraorder Polychelida in Potiguar Basin, northeastern Brazil. Specimens were collected by the project "Avaliação da Biota Bentônica e Planctônica na porção offshore das Bacias Potiguar e Ceará", developed by the Brazilian Oil Company (PETROBRAS). Three species were recorded for the first time in this region: Pentacheles validus A. Milne-Edwards, 1880, Polycheles typhlops Heller, 1862, and Stereomastis sculpta (Smith, 1880) at $2000 \mathrm{~m}, 400 \mathrm{~m}$ and $2057 \mathrm{~m}$ depth, respectively. The Brazilian deep-sea floor remains poorly known, but progress has been made as a result of collections obtained by oceanographic expeditions and research projects developed by PETROBRAS in Campos Basin (Rio de Janeiro) and Potiguar Basin (Rio Grande do Norte), expanding the knowledge of the distribution area of Polychelidae in Brazilian deep sea waters.
\end{abstract}

Key words: deep sea biota, Potiguar Basin, polychelids, Atlantic Ocean, taxonomy.

\section{INTRODUCTION}

Deep-sea blind lobsters belong to the infraorder Polychelida Scholtz and Richter, 1995. These uncommon crustaceans are characterized by the presence of chelate pereiopods $1-4$ (sometimes also pereiopod 5) and fixed and rudimentary eye-stalk in extant species (Galil, 2000). These decapods can be found from less than $100 \mathrm{~m}$ in the lower slope and in abyssal depths down to $5000 \mathrm{~m}$ (Galil, 2000; 2013).

Polychelids were most morphologically diverse during Mesozoic (Audo et al., 2014), with five families recognized: Eryonidae De Haan, 1841, Coleiidae Van Straelen, 1924, Tetrachelidae Beurlen, 1930 and Polychelidae Wood-Mason, 1874. The latter family is the only extant and currently comprises about 38 species distributed in six genera (Ahyong, 2009; De Grave et al., 2009; Chan, 2010). These crustaceans are considered as "living fossils" because of their rudimentary morphological characters which give them a primitive appearance in relation to other decapod groups (Galil, 2000).

The polychelids are members of the deep sea biota and are considered very rare and little known. The knowledge about this group derives from a small number of specimens collected by deep sea cruises and scattered in distant museums (Galil, 2000). In Brazil, in a general way, deep sea fauna remains poorly known, but progress has been made as a result of collections obtained by oceanographic expeditions and research projects developed by PETROBRAS in Campos Basin (Rio de Janeiro) and Potiguar Basin (Rio Grande do Norte), raising the number of crustaceans species known from Brazilian waters.

As a result, to date five polychelid species have been recorded from Brazil: Pentacheles laevis Bate, 1878, Pentacheles validus A. Milne-Edwards, 1880, Polycheles typhlops Heller, 1862, Stereomastis sculpta (Smith, 1880), and Stereomastis nana (Smith, 1884) (Dall'Occo and Tavares, 2004; Alvarenga and 
Cardoso, 2014). We report herein the occurrence of three Polychelidae species in Potiguar Basin, northeastern Brazil, expanding the knowledge of the distribution area of Polychelidae in Brazilian deep sea waters.

\section{Materials ANd Methods}

The material was collected on board the RV Seward Johnson on the upper part of the continental slope (150 m depth) off the Potiguar Basin, in cruises carried out in May 2009 and April 2011. The samples were collected under the framework of the project "Avaliação da Biota Bentônica e Planctônica na porção offshore das Bacias Potiguar e Ceará", developed by the Brazilian Oil Company (PETROBRAS). All samples were obtained using a box-corer $\left(50 \mathrm{~cm}^{3}\right)$ or van Veen grab $(70 \mathrm{l})$.

The specimens were identified following Ahyong and Brown (2002), and Dall'Occo and Tavares (2004). The classification adopted in the present contribution followed De Grave et al. (2009) proposed scheme to genus level. Terminology used followed Galil (2000) and abbreviations used include: (CL) carapace length (the distance from tip of rostrum to the middle of the posterior border of the carapace); (st.) station of collection. A restricted synonymy was provided for all species.

The material was deposited in Carcinological Collection of Museu de Oceanografia of Universidade Federal de Pernambuco, Recife, Pernambuco, Brazil (MOUFPE).

\section{SystemaTiCS}

\section{Infraorder Polychelida Scholtz and Richter, 1995}

\section{Family Polychelidae Wood-Mason, 1875}

Genus Pentacheles Bate, 1878

\section{Pentacheles validus A. Milne-Edwards, 1880 (Fig. 1)}

Pentacheles validus A. Milne-Edwards, 1880: 65; Bouvier, 1925: 434; Galil, 2000: 308-311, fig. 10; Ahyong and Brown, 2002: 49; Ahyong,

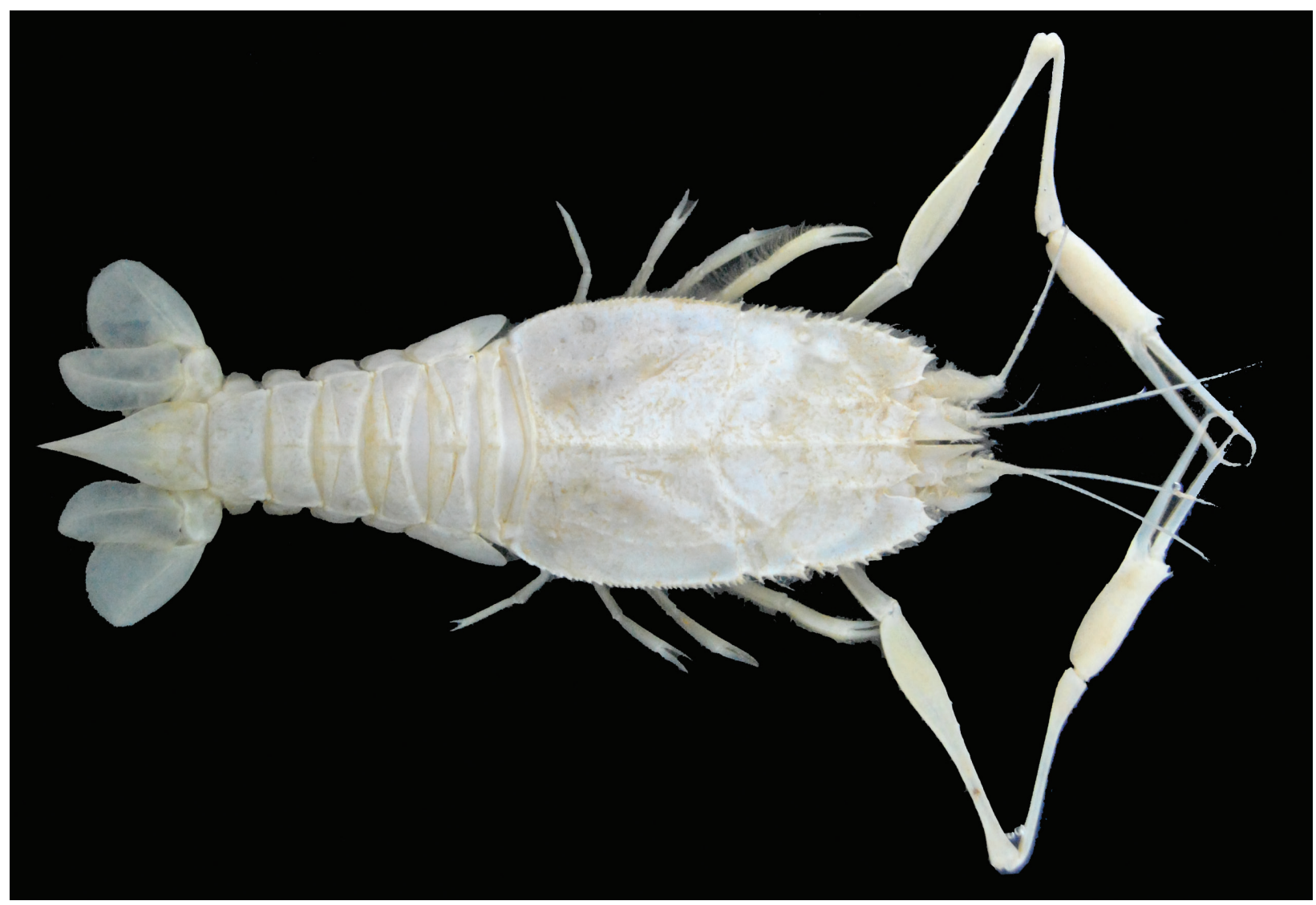

Figure 1. Pentacheles validus A. Milne-Edwards, 1880, male from Potiguar Basin, northeastern Brazil. Dorsal view. CL 50.4 mm. MOUFPE 15071. Photo by Arthur Anker. 
2009: 383; Chan, 2010: 162.

Polycheles debilis Smith, 1884: 360.

Polycheles validus Bouvier, 1905: 480; 1925: 434, fig. 10, pl. 5, figs. 1, 2; Firth and Pequegnat, 1971: 61 .

Polycheles demani Stebbing, 1917: 28, pl. XCII; Firth and Pequegnat, 1971: 45.

Polycheles chilensis Sund, 1920: 226; Firth and Pequegnat, 1971: 42.

Type locality: Bequia, Windward Islands, Antilles.

Material examined: 1 male, CL $50.4 \mathrm{~mm}$, Brazil, Rio Grande do Norte, Potiguar Basin, st. MT 85, 04º21.3'S / 3644'W, 4.iv.2011, 2057 m (MOUFPE 15071).

Diagnosis: Epipod of third maxilliped longer than ischium; basal antennular segment proximally quadrate, lamellar. Lateral margins of carapace posterior to postcervical incision with more than 25 spines.

Distribution: Worldwide - Eastern Pacific: Chile; Indo-Pacific: East Indian Ridge, Vanuatu, Wallis and Futuna Islands, New Caledonia, Australian
Bight, New Zealand and Tasmania; Eastern Atlantic: Bay of Biscay, Azores, Canary Islands, West Africa and South Africa; Western Atlantic: United States, Bahamas Islands, Gulf of Mexico, Caribbean Sea (Galil, 2000), Brazil: Rio de Janeiro (Dall'Occo and Tavares, 2004) and Rio Grande do Norte (present contribution) and South Georgia Island (Galil, 2000); depth range: 914-3365 m (Firth and Pequegnat, 1971; Galil, 2000).

\section{Genus Polycheles Heller, 1862}

\section{Polycheles typhlops Heller, 1862}

(Fig. 2)

Polycheles typhlops Heller, 1862: 392, pl. 1, figs. 1-6; Bouvier, 1925: 237; Galil, 2000: 354, fig. 30; Silva et al., 2003: 27-28; Ahyong and Chan, 2004: 179-181, figs. 1D-F, 4H, 5A, B; Dall'Occo and Tavares, 2004: 146-148, figs. 1D, 2A; Ahyong and Galil, 2006: 765-766; Coelho et al., 2007: 7; Ahyong and Chan, 2008: 64, fig. 1C; Chan, 2010: 162; Chang et al., 2013: 9-10; Galil, 2013: 497-498, fig. 1 B.

Pentacheles agassizi A. Milne-Edwards, 1880: 65. Pentacheles hextii Alcock, 1894: 237-239.

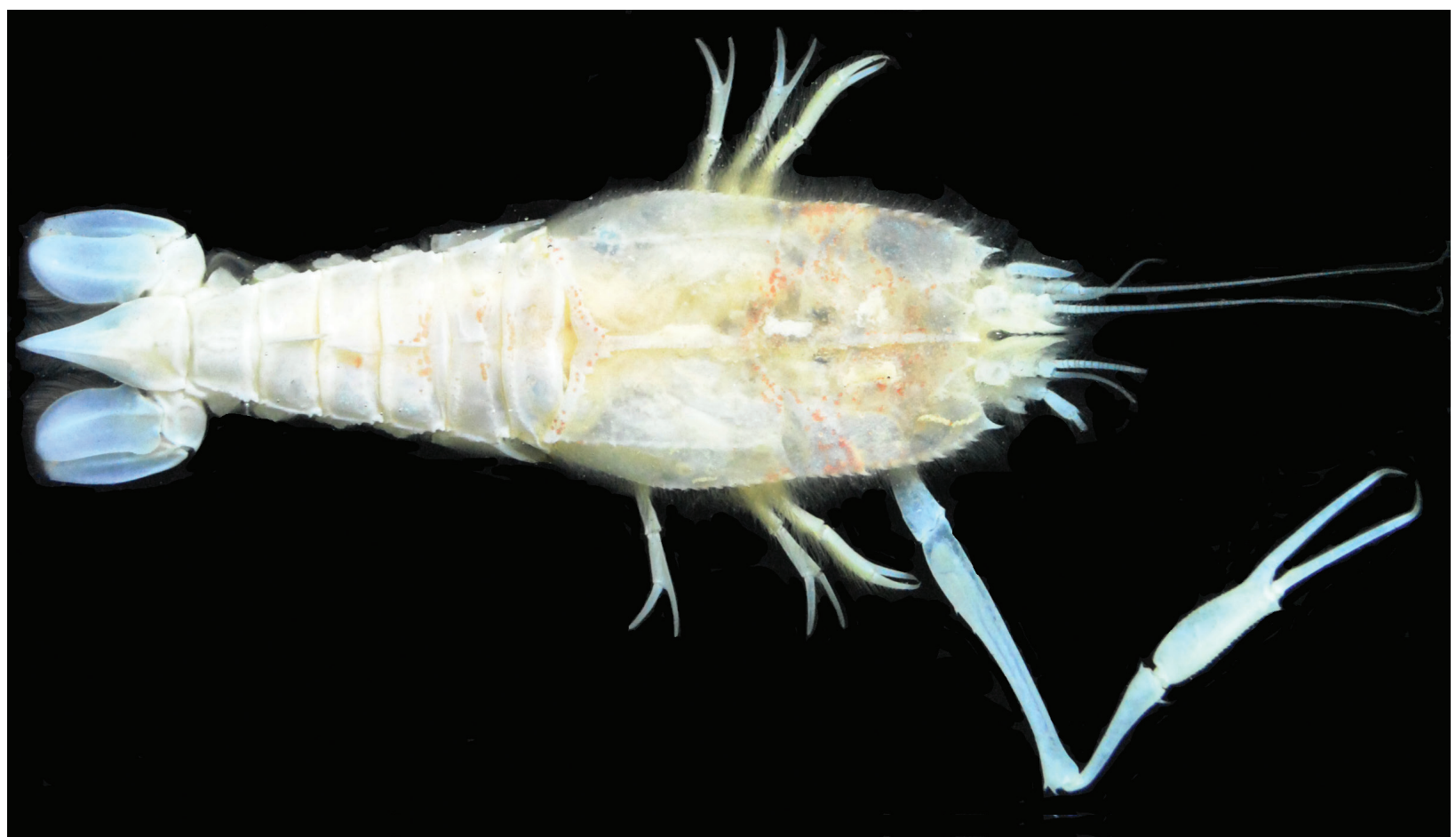

Figure 2. Polycheles typhlops Heller, 1862, female from Potiguar Basin, northeastern Brazil. Dorsal view. CL 30.52 mm. MOUFPE 15073. Photo by Arthur Anker. 
Polycheles intermedius Balss, 1914: 599.

\section{Type locality: Sicily, Italy.}

Material examined: 1 female, CL $30.52 \mathrm{~mm}$, Brazil, Rio Grande do Norte, Potiguar Basin, st. MT 65, 04033S / 3653'W, 6.iv.2011, 400 m (MOUFPE 15073).

Diagnosis: Epipod of third maxilliped rudimentary; basal antennular segment proximally rounded. One rostral spine; posterior margin of carapace armed with three or more pairs of spines.

Distribution: Worldwide - Indo-Pacific: Japan, East China Sea, Taiwan, Philippines, New Caledonia, Fiji Island, Gulf of Aden, Kenya, Comoro Island, Mozambique, Madagascar, Indonesia and Australia (Galil, 2000); Eastern Atlantic: North Sea, North Africa, Cape Verde Islands, West Africa and South Africa; Mediterranean Sea - Israel, Spain and France; Western Atlantic: United States, West Indies, Bermuda, Gulf of Mexico, Caribbean Sea, Puerto Rico (Galil, 2000), Suriname, French Guyana and Brazil: Pará, Rio de Janeiro, São Paulo, Paraná, Santa Catarina, Rio Grande do Sul
(Dall'Occo and Tavares, 2004) and Rio Grande do Norte (present contribution); depth range: $77 \mathrm{~m}$ - 2055 m (Adensamer, 1898; Galil, 2000).

\section{Genus Stereomastis Bate, 1888}

\section{Stereomastis sculpta (Smith, 1880)}

(Fig. 3)

Polycheles sculptus Smith, 1880: 346; Bouvier, 1925: 438; Galil, 2000: 340, fig. 24; Ramos-Porto et al., 2000: 250; Ahyong and Brown, 2002: 7578; Ahyong and Chan, 2004: 179, fig. 3E, G; Dall'Occo and Tavares, 2004: 146, fig. 1C; Ahyong and Galil, 2006: 765; Coelho et al., 2007: 7.

Stereomastis sculpta Ahyong 2009: 385; Chan 2010: 382.

Type locality: Nova Scotia, Canada.

Material examined: 1 female, CL $32.07 \mathrm{~mm}$, Brazil, Rio Grande do Norte, Potiguar Basin, st. 85-2, 0425's / 36²0'W, 15.iv.2011, $2000 \mathrm{~m}$ (MOUFPE 15072).

Diagnosis: Epipod of third maxilliped

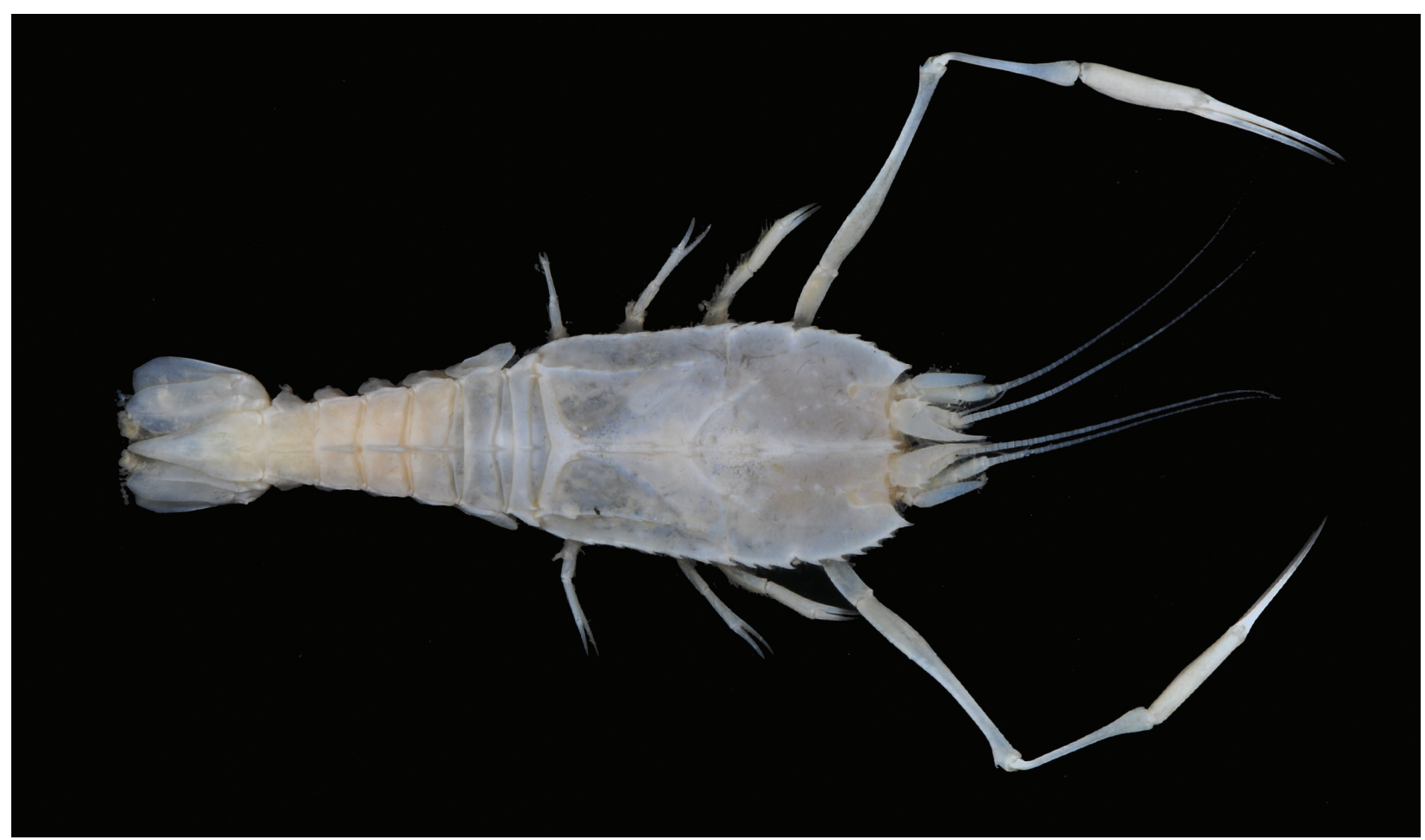

Figure 3. Stereomastis sculpta (Smith, 1880), female from Potiguar Basin, northeastern Brazil. Dorsal view. CL 32.07 mm. MOUFPE 15072. Photo by L.E.A. Bezerra. 
rudimentary; basal antennular segment proximally rounded. Two rostral spines; posterior margin of carapace armed with one pair of submedian spines only.

Distribution: Worldwide - Eastern Pacific: Canada, United States and Chile; Indo-Pacific: Japan, China Sea, Philippines, Indonesia, Malay Archipelago, Australia, Tasmania, Vanuatu, New Zealand, Arabian Sea, East Africa, Gulf of Aden, Comoro Islands and Madagascar; Mediterranean Sea; Eastern Atlantic: Ibero-Moroccan Gulf, Mauritania, Canary Islands, Cape Verde islands, West Africa and South Africa; Western Atlantic: Labrador Sea, Canada, Iceland, United States, Gulf of Mexico, Caribbean Sea, Guyana (Galil, 2000) and Brazil: Pará, Espírito Santo, Rio de Janeiro, São Paulo, Paraná, Santa Catarina (Dall'Occo and Tavares, 2004) and Rio Grande do Norte (present contribution); depth range: $200 \mathrm{~m}-4000 \mathrm{~m}$ (Stephensen, 1923; Galil, 2000).

\section{DisCUSSION}

The present contribution reveals the occurrence of three polychelid species on the Brazilian northeastern coast, filling a gap of distribution of approximately $23^{\circ}$, between the north and south Brazil (Fig. 4). Pentacheles validus was first reported to Brazil by Dall'Occo and Tavares (2004), who examined material collected by the RV Marion Dufresne off the southeastern coast of Brazil. The present report is the second one from Brazil, as well as the northernmost occurrence of this species in Brazilian waters.

Polycheles typhlops is worldwide distributed and the most abundant species in Brazilian waters, once 33 specimens were reported by Dall'Occo and Tavares (2004) from the southeastern Brazil and one specimen recorded from Pará State, northern Brazil (Silva et al., 2003). This study brought an additional record of this species for Brazil, being the first record for northeastern coast.

Finally, Stereomastis sculpta was previously identified as Polycheles sculptus (Galil, 2000; Ahyong and Chan, 2004; Dall'Occo and Tavares, 2004; Ahyong and Galil, 2006) because Galil (2000) synonymised the genus Stereomastis with

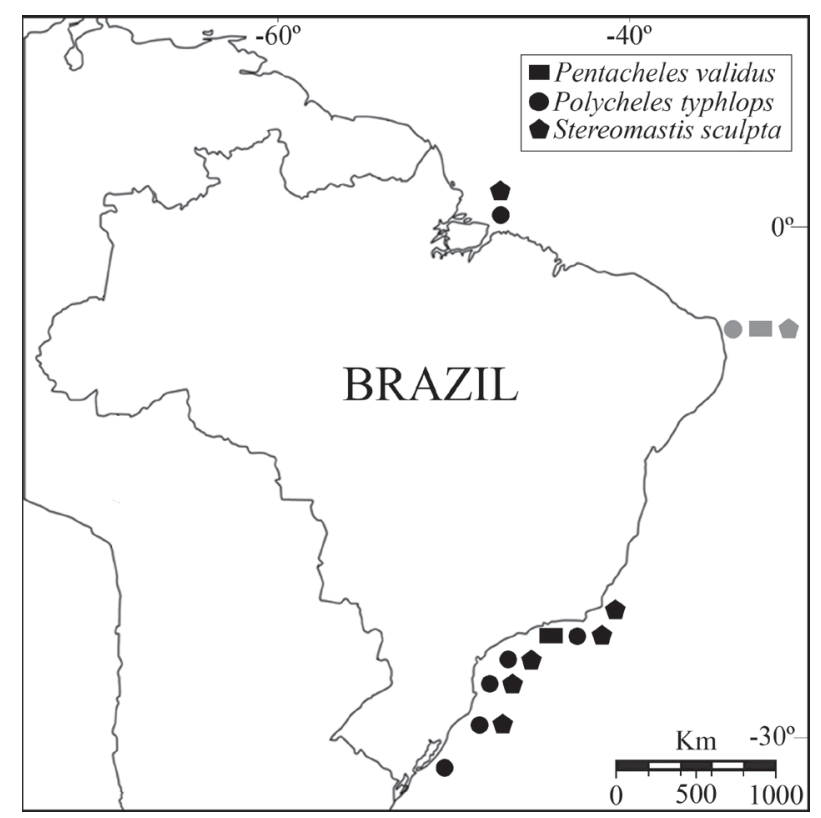

Figure 4. Distribution of Pentacheles validus, Polycheles typhlops and Stereomastis sculpta in Brazil. Previous distribution in Brazil (black symbols). Occurrence in Potiguar Basin, northeastern Brazil (grey symbols).

Polycheles. However, after a phylogenetic analysis, Ahyong (2009) concluded that both genera were monophyletic and morphologically distinct, placing then P. sculptus in the genus Stereomastis. Stereomastis sculpta is also worldwide distributed and previously reported to Brazil from two specimens from Pará (Ramos-Porto et al., 2000), and seven specimens recorded from southeastern and southern Brazil (Dall'Occo and Tavares, 2004). This present record extends the range of occurrence of $S$. sculpta in Brazil, consisting in the first record for northeastern coast.

In conclusion, this contribution extends the known Brazilian distribution of Polychelida species. We suggest that these species could be more frequent in deep sea Brazilian floor. Taking into account that this is an understudied group, more sampling is needed to describe the diversity of these deep sea crustaceans, and even biological aspects such as reproductive period and fecundity.

\section{ACKNOWLEDGMENTS}

Thanks to Petróleo do Brasil S/A (PETROBRAS) for making available the studied samples. Special thanks to Arthur Anker for the help with the photographs. 


\section{REFERENCES}

Adensamer, T.H. 1898. Zoologische Ergebnisse. XI. Decapoden. Gesammelt auf S.M. Schiff "Pola" in den Jahren 1890-1894. Berichte der Commission fur Erforschung des Ostlichen Mittelmeeres XXII. Denkschriften der Kaiserlichen Akademie der Wissenschaften Mathematischnaturwissenschaftlicher Classe, Wien, 65: 597-628.

Ahyong, S.T. 2009. The Polychelidan Lobsters: Phylogeny and Systematics (Polychelida: Polychelidae). p. 369-396. In: J.W. Martin; K.A. Crandall and L. Felder (eds), Decapod Crustacean Phylogenetics. Crustacean Issues, Vol. 18. Boca Raton/London/New York, CRC Press/Taylor \& Francis Group.

Ahyong, S.T. and Brown, D.E. 2002. New species and new records of Polychelidae from Australia (Decapoda: Crustacea). Raffles Bulletin of Zoology, 50: 53-79.

Ahyong, S.T. and Chan, T.Y. 2004. Polychelid lobsters of Taiwan (Decapoda: Polychelidae). Raffles Bulletin of Zoology, 52(1): 171-182.

Ahyong, S.T. and Chan, T.Y. 2008. Polychelidae from the Bohol and Sulu Seas collected by Panglao 2005 (Crustacea: Decapoda: Polychelidae). Raffles Bulletin of Zoology, Suppl. 19: 63-70.

Ahyong, S.T. and Galil, B.S. 2006. Polychelidae from the southern and western Pacific (Decapoda, Polychelida). Zoosystema, 28(3): 757-767.

Alcock, A. 1894. Natural history notes from H.M. Indian marine survey steamer "Investigator", Commander R.F. Hoskyn, R.N., commanding. Ser. II., No. 1. On the results of deep-sea dredging during the season 1890-91. Annals and Magazine of Natural History, London, 13(6): 225-245.

Alvarenga, F.M. and Cardoso, I.A. 2014. First record of Stereomastis nana (Polychelidae: Crustacea: Decapoda) from the south-western Atlantic. Marine Biodiversity Records, 7: e80, 1-4.

Audo, D.; Schweigert, G.; Saint Martin, J.P. and Charbonnier, S. 2014. High biodiversity in Polychelida crustaceans from the Jurassic La Voulte-sur-Rhône Lagerstätte. Geodiversitas, 36(4): 489-525.

Balss, H. 1914. Diagnosen neuer Macruren der "Valdivia" Expedition. Zoologischer Anzeiger, Leipzig, 44: 592-599.

Bate, C.S. 1878. On the Willemoesia group of Crustacea. LV. Annals and Magazine of Natural History, London, 5(2): 484-487.

Bate, C.S. 1888. Report on the Crustacea Macrura dredged by H.M.S. "Challenger" during the years 1873-1876. Report on the Scientific Results of the Voyage of H.M.S. "Challenger" during the Years 1873-76, Zoology, 24: 1-942, 154 pls.

Beurlen, K. 1930. Vergleichende Stammesgeschichte Grundlagen, Methoden, Probleme unter besonderer Berücksichtigung der höheren Krebse. Fortschritte in der Geologie und Paläotologie, 8: 317-586.

Bouvier, E.L. 1905. Sur les Palinurides et les Eryonides recueillis dans l'Atlantique oriental par les expéditions francaises et monégasques. Comptes Rendus des Séances de l'Académie des Sciences, 140: 479-482.
Bouvier, E.L. 1925. XLVIII. Les Macroures marcheurs. Reports on the Results of Dredging, under the Supervision of Alexander Agassiz, in the Gulf of Mexico (1877-78), in the Caribbean Sea (1878-79), and along the Atlantic Coast of the United States (1880), by the U.S. Coast Survey Steamer "Blake", Lieut. Commander CD. Sigsbee U.S.N., and Commander J.R. Bartlett, U.S.N., Commanding. Memoirs of the Museum of Comparative Zoology at Harvard College, Cambridge, 47(5): 401-472, 11 pls.

Chan, T.Y. 2010. Annotated checklist of the world's marine lobsters (Crustacea: Decapoda: Astacidea, Glypheidea, Achelata, Polychelida). Raffles Bulletin of Zoology, 23: 153-181.

Chang, S.C.; Ahyong, S.T. and Chan, T.Y. 2013. New records of deep-sea blind lobsters (Crustacea: Decapoda: Polychelidae) from Taiwan. Journal of Marine Science and Technology, 21: 8-14.

Coelho, P.A.; Almeida, A.O.; Bezerra, L.E.A. and Souza-Filho, J.F. 2007. An updated checklist of decapod crustaceans (infraorders Astacidea, Thalassinidea, Polychelida, Palinura, and Anomura) from the northern and northeastern Brazilian coast. Zootaxa, 1519: 1-16.

Dall'Occo, P.L. and Tavares, M. 2004. New and additional records of deep-water lobsters from Brazil (Decapoda, Polychelidae). Nauplius, 12(2): 143-149.

De Grave, S; Pentcheff, N.D.; Ahyong, S.T.; Chan, T.; Crandall, K.A.; Dworschak, P.C.; Felder, D.L.; Feldman, R.M.; Fransen, C.H.J.M.; Goulding, L.Y.D.; Lemaitre, R.; Low, M.E.Y.; Martin, J.W.; Ng, P.K.L.; Schweitzer, C.E.; Tan, S.H.; Tshudy, D. and Wetzer, R. 2009. A classification of living and fossil genera of decapod crustaceans. Raffles Bulletin of Zoology, Suppl. 21: 1-109.

Firth, R.W. and Pequegnat, W.E. 1971. Deep sea lobsters of the families Polychelidae and Nephropidae (Crustacea, Decapoda) in the Gulf of Mexico and Carribean Sea. Department of Oceanography, Texas A\&M University, Texas, 106p.

Galil, B.S. 2000. Crustacea Decapoda: Review of the genera and species of the family Polychelidae Wood-Mason, 1874. In: A. Crosnier (ed), Résultats des Campagnes MUSORSTOM, Volume 21. Mémoires du Muséum national d'Histoire naturelle, Paris, (Zoologie), 184: 285-387.

Galil, B.S. 2013. On a collection of Polychelidae from Papua New Guinea (Crustacea, Decapoda, Polychelida). Zoosystema, 35(4): 495-502.

Haan, W. de. 1833-1850. Crustacea. In: P.F. Von Siebold, Fauna Japonica sive Description animalium, quae in itinere per Japoniam, jussus et auspiciis superiorum, qui summun in India Batava Imperim tenent, suscepto, annis 18231830 collegit, notis, observationibus e adumbrationibus illustravit. Lugduni Batavorum, fasc. 1-8: i-xvii, i-xxxi, 1-224, pl. 1-55, A-Q, 1-2. 
Heller, C. 1862. Beitrage zur naheren Kenntnis der Macrouren. Sitzungsberichte der Akademie der Wissenschaften in Wien, mathematisch-physikalische Klasse, 45(1): 389-426, 2 pls.

Milne-Edwards, A. 1880 . No. 1. Reports on the results of dredging under the supervision of Alexander Agassiz, in the Gulf of Mexico, and in the Caribbean Sea, 1877, 78, 79 , by the MS coast survey steamer Blake. VIII. Études préliminaires sur les Crustacés. Bulletin of the Museum of Comparative Zoology of Harvard College, 8: 1-68, pls 1-2.

Ramos-Porto, M., Viana, G.F.S., Silva, K.C.A., Cintra, I.H.A., and Coelho, P.A. 2000. Stereomastis sculpta (Smith, 1880) (Decapoda: Polycheloidea: Polychelidae) in Brazilian waters. Nauplius, 8(2): 249-251.

Scholtz, G. and Richter, S. 1995. Phylogenetic systematics of reptantia Decapoda (Crustacea, Malacostraca). Zoological Journal of the Linnean Society, 113: 289-328.

Silva, K.C.A., Cintra, I.H.A., Ramos-Porto, M. and Viana, G.F.S. 2003. Lagostas capturadas durante pescarias experimentais para o Programa REVIZEE/NORTE (Crustacea, Nephropoidea, Eryonoidea, Palinuroidea). Boletim Técnico Científico do CEPNOR, 3(1): 21-35.
Smith, S.I. 1880. Notice of a new species of the "Willemoesia Group of Crustacea", recent Eryontidae. Proceedings of the United States National Museum, 2: 345-353.

Smith, S.I. 1884. XV. Report on the Decapod Crustacea of the "Albatross" Dredgings off the East-coast of the United States in 1883. Report of the United States Fish Commission, Washington, 10(1882): 345-426, pls 1-10.

Stebbing, T.R.R. 1917. IX. South African Crustacea. Annals of the South African Museum, Cape Town, 17, pt 1:23-46, pls $1-8$.

Stephensen, K. 1923. Decapoda Macrura excel. Sergestidae. Report on the Danish oceanographical Expeditions 1908/10 to the Mediterranean and adjacent sea, 2: 1-85.

Sund, O. 1920. The "Challenger" Eryonidea (Crustacea). Annals and Magazine of Natural History, London, 6(9): 220-226.

Van Straelen, V. 1924. Sur Pseudoglyphea et Scapheus Crustacés Decapodes du Lias. Bulletin de la Classe de Sciences Academie Royale de Belgique, Bruxelles, 10: 219-228.

Wood-Mason, J. 1874. On blind crustaceans. Proceedings of the Asiatic Society of Bengal, 1874: 180-181 
